\title{
Project Managers Perceptions about more Effective Leadership Styles
}

\author{
${ }^{1}$ Maria José Sousa, ${ }^{2}$ Ivo Dias, ${ }^{3}$ Isabel Moço, ${ }^{4}$ Ana Saldanha, ${ }^{5}$ Carla Caracol \\ 1234 Universidade Europeia, Lisboa Portugal, ${ }^{5}$ Universidade Lisboa, Portugal
}

\begin{abstract}
2017 Research Leap/Inovatus Services Ltd. All rights reserved.

DOI: 10.18775/jibrm.1849-8558.2015.23.3001 URL: http://dx.doi.org/10.18775/jibrm.1849$\underline{8558.2015 .23 .3001}$

\section{Keywords:}

Transformational Leadership;

Transactional Leadership;

Project Management..

The main purpose of this study is to analyze the type of leadership that can be more effective in the perceptions of project managers. In this case, the research question answer could have a major meaning due to the fact that projects rarely fail due to the lack of professional skills and knowledge; they most often fail because of the type of leadership. The research question is "Which are the most effective leadership style for project managers?" The methodology used was quantitative through the application of a questionnaire to 78 project managers and the results shows that Transformational Leaders are the most effective according the specificities of the projects.
\end{abstract}

\section{Introduction}

The existence of increasingly competitive markets has made imperative that either the companies possess ever-growing and flexible organizational structures or to ensure that the successes previously achieve can be replicated in future situations (Gomes \& Romao, 2015). Similarly, and in the field of project management, it is expected that the results obtained in previous projects, namely the procedures followed, can be followed in future cases

Both project management and the roles and responsibilities assigned to the project managers have evolved significantly in recent decades. The practices and techniques used by project managers have become differentiating competencies in the achievement of competitive advantages in the fulfillment of organizational aims. Identifying these skills and their measurement have become a concern, considering that its detention promotes the ability to implement process improvement of the company's ability to adapt itself to the market environment, through efficiencies and effectiveness of tasks associated with project management, regarding a diagnosis frame of strengths and weaknesses and internalizing the gains and the benefits identified in other companies of the same sector or not (Gomes \& Romao, 2015).

The project management model adopted in each concrete situation, as stated by Eskerod \& Riis (2009: 4), shows and specifies the management breakdown structure, the management processes, and the roles in project management. Because the projects are seen as a powerful development and organizational change tool, studies on the level of success of the project management focus on issues such as, how to measure success, the factors that affect it, or both. It should be noted, however, that success can be perceived differently by different stakeholders (Gomes \& Romao, 2015).

\section{Literature Review}

\subsection{Project Management Models}

In the recent decades, and based on the Capability Maturity Model, new approaches to assessing the capabilities and the maturity of the various project management models were born to light. we. Based, in general, in the application of questionnaires, considering multiple dimensions and components, models like the K-PMMM (Project Management Maturity Model, Kerzner) and PMS-PMMM (Project Management Maturity Model, Project Management Institute), the PM2 (Berkeley Project Management Process Maturity Model), the OPM3 (proposed by PMI American Project Management Institute) and the P2CMM Project Management Maturity Model, among many others, have been evaluating the ability of these models to work as support tools to the strategic planning, decision, and other activities in the various management levels of responsibility (Lianying, Jing \& Xinxing, 2012).

The project management maturity models aim integration, evaluation and improvement of project management practices and the level of development stems from the company's ability to incorporate the use of IT in the design, development and implementation of organizational information systems (Alami, Bouksouri, \& Beidouri, 2015; Andersen \& Jessen, 2003; Lianying, Jing \& Xinxing, 2012).

In this context, the maturity and competence held in project management play a critical role in this capacity of business reaction to the challenges of unpredictable and unstable markets, in the resolution of critical problems for the company (Alami, Bouksouri, \& Beidouri, 2015; Andersen \& Jessen,2003; Gomes \& Romao, 2015). If we consider that maturity in project management can be understood as a system of replication, processes and procedures which are capable of generating a successful implementation of new projects, and the ability of organizations to use project management for different purposes 
(Andersen \& Jessen, 2003), it is widely perceived that the emergence of project management maturity models has been gaining and important place in literature.

According to Andersen \& Jessen (2003), maturity must be understood in a broader sense, combining behavior and competence, as the sum of action (ability to act and decide), attitude (willingness to be Involved) and knowledge (an understanding of the impact of the willingness and action), while dimensions of that maturity (Andersen \& Jessen, 2003: 458). In this sense, the evaluation of the degree of maturity of project management tends to focus on the response to questions directed to project management knowledge, project management attitude and current project management practices.

If, on one hand, knowledge is a determinant factor in many of the decisions and actions taken, on the other hand, the attitude, and especially the attitude towards the change, was established as the generator motor of the need for development, as expressed in the System Dynamics 'model defined by Forrester (Jessen \& Andersen, 2003). This proposition seems to challenge the legitimacy of the traditional approach to sequence knowledge, attitude and action, opposing to it a new sequence - attitude, knowledge and action.

In the performed research, based on the contribution of several authors, Andersen \& Jessen (2003: 458-9) proceed to the construction of an analytical model around the concepts of attitude, knowledge and action, which form the construct maturity, considering the following dimensions: (1) For Attitude: Attitudes towards risk and insecurity ( "uncertainty avoidance "); Attitudes towards power and responsibility sharing ("power distance"); Attitudes towards hard and soft values ("masculinity and femininity"); and Attitudes towards co-operation (" individualism and collectivism"), (2) For Knowledge: Knowledge about suppositions ( " the input "); Knowledge about ways of working ( " the work processes'); Knowledge about desirable results ( " the output "); and Knowledge about totality ( " the holism "), (3) For Action Action taken at level strategic (top management level, level CEO); Action taken at level tactical (line management, program management, portfolio management); Action taken at level administrative (administrative support functions); and Action taken at operational level (project management, project participants).

The application of a questionnaire based on these 3 dimensions and their respective components will assess the project management maturity level, which the authors consider to be a process divided in stages, in which, starts from the lowest level - Project Management - with an individualized project management, through an intermediate level Program management - the management of several projects subordinated to the same goal, to the highest level - Portfolio management - including multiple projects oriented to different goals, regardless of the projects pursuing operational, tactical or strategic objectives (Jessen \& Andersen, 2003).

Achieving success in project management, particularly with regard to meeting deadlines, costs and technical specifications, has as its basic requirement the detention of skills from their stakeholders. However, while based on processes, tools and techniques, hard skills have been overvalued at the expense of soft skills as a critical success factor in project management, although multiple studies lead to the conclusion that it is the lack of integration between these two types of skills the primary reason for the failure of multiple projects (Sukhoo, Barnard, Eloff, \& Van der Poll, 2005).

Due to the involvement of intangible dimensions, such as the involvement of elements of the project groups, customer satisfaction, among others, the activation of soft skills has been considered critical in achieving high levels of performance in project management terms, despite the availability of hard skills being regarded as a basic requirement. Among many other dimensions, have been considered to be necessarily present in project management, soft skills such as communication skills, team building, flexibility and creativity, leadership, organizational effectiveness, stress management, time management, change management, trustworthiness and conflict management.

Sukhoo et al. (2005), in a software project management applied study, identify soft skills to enable, and considered to be critical, depending on the different stages of project management, as stated in Table I regardless of the nature, activity or cultural context sector where they occur. The same authors believe that other soft skills can be mobilized and that arise associated with the emotional intelligence construct.

Table 1 - Soft skills activation

\begin{tabular}{|l|c|c|c|c|c|}
\hline \multirow{2}{*}{ Soft Skills } & \multicolumn{5}{|c|}{ Project Management Phases } \\
\hline & Initiating & Planning & Executing & Controlling & Closing \\
\hline $\begin{array}{l}\text { Comunnication } \\
\text { skills }\end{array}$ & & & $\sqrt{ }$ & $\sqrt{ }$ & $\sqrt{ }$ \\
\hline Team building & & & $\sqrt{ }$ & & \\
\hline $\begin{array}{l}\text { Flexibility and } \\
\text { creativity }\end{array}$ & $\sqrt{ }$ & $\sqrt{ }$ & $\sqrt{ }$ & & \\
\hline Leadership & & & $\sqrt{ }$ & $\sqrt{ }$ & \\
\hline $\begin{array}{l}\text { Organizational } \\
\text { effectiveness }\end{array}$ & & $\sqrt{ }$ & $\sqrt{ }$ & & \\
\hline $\begin{array}{l}\text { Stress } \\
\text { management }\end{array}$ & & & $\sqrt{ }$ & $\sqrt{ }$ & \\
\hline $\begin{array}{l}\text { Time } \\
\text { management }\end{array}$ & & $\sqrt{ }$ & $\sqrt{ }$ & & \\
\hline $\begin{array}{l}\text { Change } \\
\text { management }\end{array}$ & & & $\sqrt{ }$ & $\sqrt{ }$ & \\
\hline Trustworthiness & & & $\sqrt{ }$ & $\sqrt{ }$ & \\
\hline $\begin{array}{l}\text { Conflict } \\
\text { management }\end{array}$ & & & $\sqrt{ }$ & \\
\hline
\end{tabular}

Source: Sukhoo, Barnard, Eloff, \& Van der Poll (2005: 699-70)

Regarding the Maturity Model design process, coexist different proposals from different authors, which stipulate the existence in several phases. Alami et al (2015) have adopted the design proposed by Becker, Knackstedt \& Pöppelbuß, which identifies six phases: (1) Scope The scope phase defines the focus and Identifies the relevant stakeholders and targeted Audiences. It Determines the balance between complex reality and simplicity model; (2) Design. The design phase addresses the requirements-based design and outlines the main concept of maturity, structure of levels, dimensions and sub-dimensions (the meta-model); (3) Populate. In the populate phase, the Corresponding characteristics are determined and the maturity assessment is defined, which includes the specification of assessment instruments; (4) Test The constructed model is tested on content and completeness intended scope model accuracy and the assessment instrument is tested for validity and reliability; (5) Deploy. The model is deployed to the initial stakeholders and to an independent community; (6) Maintain. Once deployed, the model needs to be kept in 
use and for a sufficient period of time-say, a couple of years to ensure its evolution.

\subsection{Leadership Theories: LEADERSHIP - a Construct Evolving}

The study of the expression and of the impact of leadership is a recurring theme in academic and professional environment. Leadership is effectively a widely studied phenomenon as can be seen in (Bass \& Stogdill, 1990), in which the authors refer about 7,500 studies on the subject, implying that any angle of the phenomenon that is to be studied, requires hard work positioning conceptual.

Management literature considers leadership a success factor in organisations and that specific leadership style can lead to better performance. According to Levin there are three major leadership styles (Lewin et al., 1939): a) autocratic leaders, make decisions without consulting their team members. This can be appropriate when decisions need to be made quickly, when there's no need for team input, and when team agreement isn't necessary for an outcome. However, this style can lead to high levels of absenteeism and staff turnover; b) democratic leaders, make the final decision, but they include team members in the decision-making process. They encourage creativity and employees are often highly engaged in projects and decisions. As a result, team members tend to have high job satisfaction and high productivity; c) laissez-faire, leaders give their team members a lot of freedom to do their work, and to set their deadlines. They provide support with resources and advice if needed, but otherwise they don't get involved. This autonomy can lead to high job satisfaction, but it can be difficult if team members don't have knowledge, skills, or self-motivation to do their work effectively.

The contingency school (Fiedler, 1996) suggest that what makes an effective leader would depend on the situation. The behavioural school also assumed that effective leaders adopt certain styles (Hersey \& Blanchard, 1988), especially the ones studied in theory X and theory Y: a) theory $X$ managers believe that the average employee has an inherent dislike of work and will avoid it if possible, they avoid responsibilities and have relatively little ambition. b) Theory Y managers believe that the expenditure of physical and mental effort in work is something natural, and the average employees, under proper conditions, learns not only to accept but to seek responsibility.

Moreover, it is considered, more or less widespread, the existence of three major theoretical paradigms on Leadership: a first one very focused in the profile and leading conditions; a second one concerned with an indication of leadership behaviors which are more effective and a third one, more aggregator, which explores the contingent variables that determine the success of leadership, either as background or even as consequential.

Burns (1978), based on a study of political leaders, proposes that the leader types are to be presented in a continuum of behaviors ranging from transactional to transformational, arguing that transformational leadership is revealed when the leader can stimulate the followers to develop certain types of behaviors, which is done beyond their personal interests and motivations, focused only in the best interests of those they serve - the group and the organization. The model estimates that this type of leadership develops and stimulates higher behaviors, even in the ethical dimension, as of the leader or of the followers. This line of thought was taken up by Bass (1985) which questions after noting that the difference would be only conceptual, as some leaders had a mix of the two roles, even if there is a clear distinction between transactional and transformational leadership.

\subsection{Leadership Skills for Project Management}

The management literature significantly explores the importance of leadership in the process, which does not happen on such a large scale on the importance of leadership in the success of project management (Turner \& Müller, 2005). Still, the relationship between the leadership style impacts on individuals, team and task, and the effects in the management of a project is significantly represented in the literature (Eskerod \& Riis, 2009; Geoghegan \& Dulewicz, 2008; Keegan \& Den Hartog, 2004; Prabhakar, 2005; Thite, 1997; Turner and Müller, 2005).

Most of the existing literature discusses and tests that the most effective leadership style to ensure the project's success, taking us to focus on the discussion of this dimension in studies focused on the Bass and Avolio continuum.

Starting from the idea that "leadership style and competence are seldom identified in the critical success factors on projects." (Turner \& Müller, 2005, p.55), Lowe, Kroeck, \& Sivasubramaniam (1996) conducted a meta-analysis which seeks to establish if there is a relationship between the $M L Q$ scaling, having identified a set of moderators: leading position in the structure; type of organization (public / proven); perception measurement criteria of the followers regarding the effectiveness of the leader, which reveal different correlations between leadership and effectiveness. The 75 studies analyzed by the authors, with tight eligibility criteria, reported a statistically significant relationship between the effective leader and 3 scales of transformational leadership (by scale measures Bass \& Avolio): Charisma, individual consideration and intellectual stimulation, while the ratio with the transactional style appears less relevant.

Although neither exhaustive nor consensus on the identification of success factors of project management, the literature contains studies that show leadership as one of them (Prabhakar, 2005). When the literature indicates it, it seems indeed that there is a relationship between leadership skills and the success of a project (Geoghegan \& Dulewicz, 2008), although it cannot be neglected neither the maturity of the project itself (Andersen \& Jessen, 2003) nor the technical expertise of the Project Leader (Thite, 1997; Turner \& Müller, 2005), which should be articulated with the human dimensions (Eskerod \& Riis, 2009). Although the powers of the Project Leader, including leadership, are required by the stage of the project life cycle (Turner \& Müller, 2005), the dimensions of Emotional Intelligence (Khan, Khan, Saeed Khan \& Sanaulla, 2011) seem positively related to the Transformational Leadership and this supports organizational outcomes. In this field, Rashid Rehman \& Waheed (2012) also note that emotional intelligence moderates the relationship between Transformational Leadership and decision - making styles, size they consider it fundamental in the success in project management. For the authors, transformational leadership is a strong predictor of rational decision making and dependent and weak in relation to making spontaneous and intuitive decision.

As Bass argues in its model, according to a set of variables switching between transactional and transformational styles will be necessary, also the work of Thite (1997) the show. Further it is also tested that the change in leadership style and in the project's success have a tight relationship (Prabhakar, 2005, p.6), although the leader of the experience is relevant and "Transformational leadership has been linked to leadership effectiveness, innovativeness and Also to the performance "(Khan, Khan, Saeed Khan, \& Sanaulla 2011, p. 44)

Studies like the one of Keegan \& Den Hartog (2004) established a relationship between transformational style, motivation, commitment and 
stress of followers, in the case of project management. "Research has also proved the existence significant and positive relationships between transformational leadership and the eagerness of followers to exercise, satisfaction, job performance, and effectiveness with their leader (Bass, 1985)." (Khan, Khan, Saeed Khan, \& Sanaulla 2011, p. 50)

\subsection{Conceptual Model of Bass and Avolio}

Long, wide and enlightening has been the discussion of the concept of transformational leadership that often considers the comparison with transactional leadership and often presents itself as more inclusive, proactive and effective, as it is not a profile that responds to the circumstances and be a source mobilization and development (House, 1976; Bass, 1985; Conger \& Kanungo, 1988; Yukl, 1989; Bass \& Avolio, 1993)

The leadership approaches of Burns (1978) and Bass (1985), as they focus primarily on the type of interaction between members - leaders and followers served as the starting point for this project. If, initially this imaginary line separating transactional leadership, widely based on the legitimacy and authority of the leader, in the exchange and in concrete in contrast, in the transformational leadership - which encompasses more values, motivation, mobilization of people and guidance for the realization of desires and needs in exchange for achievement, the development of the same eventually resulted in the proposal of a detailed set of leadership dimensions (Bass, 1998; Bass \& Avolio, 1993). The articulation of these two perspectives resulted in a complexity of the model that advances leadership profiles resulting from the crossing two variables: the effectiveness of the exercise of leadership and the involvement.

For Bass, transformational leadership is defined by the type and magnitude of the effects caused by the leader in his followers and the feedback that they give accordingly. Transformational leadership, while encouraging this interaction, promotes three effects: the followers can better share and understand common goals, the individual tends to put first the common interest over the individual interest and moral, ethical values gain expression in the behavior of the group. Bass also for the effectiveness of leadership is circumstantial, by admitting that the leader can switch between transactional and transformational behaviors. The model of Bass (1999) considers the role of leader as a responsibility associated with ethical standards, considering that the transformational leader raises levels of maturity, the needs of achievement and progress and welfare - individuals, organization and society. "(Bass, 1999). Transformational leadership is associated with very high levels of identification and commitment both between leader and the follower, and between the leader and the organization, or even between the follower and the organization (Bass \& Avolio, 2000). They question the transactional model, while not excluding it, in particular in relation to the causes of their inefficiency, registering circumstantial issues such as the effect of the pressure of time, how to measure results, the limits of positive reinforcement or even the "declassification" style face in certain situations. They conclude that the effectiveness of transactional leadership is mortgaged when the leader himself does not meet the reputation or the resources, what can happen when a leader fails. Transformational leaders are presented in the model of Bass \& Avolio (2004) as drivers of individual development of their subordinates, the group as a whole and the organization itself, stating that there is evidence that this kind of leadership is more positively related with higher levels effectiveness, both personal and organizational, which further studies reinforced (Yammarino \& Bass, 1990; Carter, Armenakis, Field \& MOSSHOLDER, 2013).
The transformational role could be trained in leaders (Avolio, Yammarino \& Bass, 1991), indicating that an effort of adjustment to the contexts and the development of this paper can be an induced situation, either by necessity or even by the effectiveness of desire. It seems, by the use of other approaches, namely Popper \& Mayseless (2007) that there are background regarding the efficiency of transformational leadership, and that the authors tested and where they identified confidence, guidance for social contact, proactive guidance and optimistic high guidance to lead, presenting themselves as the forerunners of the leadership development, designating the "building blocks of the leader development". Although the theories of transformational leadership are important to understand the process efficiency, authors such as Yukl (1999) relativize its originality, referring to the value attributed to them is exaggerated.

\subsection{Multifactor Leadership Questionnaire (MLQ)}

The proposed relationship between transactional and transformational leadership, and considering that the two are neither opposite nor contradictory, based on the idea that the first sees its enhanced effects when the leader assumes the role of transformational agent, while transactional leadership processes are associated with lower performances. But the developments of the theory which led to Bass \& Avolio, based on two decades' research, to consider also a more passive (laissez-faire), proposing a theoretical approach of "broadband" composed by crossing dimensions of analysis of three leadership models: Transformational, transactional and liabilities (Laissez-faire).

In a sequence of developed researches over the years, several authors (Avolio \& Yammarino, 1990; Bass \& Avolio 1994 2004; Antonakis \& House, 2002, 2013) managed to contribute to the clarification of the determinants of transformational leadership, with the model in question: a) Idealized Influence, where the leader assumes the reference paper for followers resulting in a high congruence between behavior of both (This has two sub-dimensions: the Idealized influence attributed related charisma attributes where led recognize the leader a source of regulation, an example and affective connection manifests and Idealized Influence revealed the charisma behaviors); b) The inspirational motivation, based on commitment to the objectives and facilitating the fulfillment of goals, even the difficult ones; c) Intellectual stimulation, challenge based on the capabilities of followers, either to the decision - making process, innovation or error correction; The Individualized Consideration, an emotional bonding factor between leader and followers which encourages the development, including through the delegation.

In case of more transactional profiles, the dimensions are different than what it is expressed, namely: a) The reward contingent, related to the exchange of materials and / or emotional resources for results; b) Management by the active exception, where the leader can punish deviations from the target and have a role of monitoring and correction; c) Management by Exception passive, where the leader acts only confronted with the diversion.

In the case of more passive styles, the authors advance that it is a position of "no leadership" of non - interference in processes or as they arise, nor in its assessment.

All this modeling work, Bass \& Avolio (1994) then propose a model The Full Range Leadership - which assumes a leadership position, each leader will manifest predominantly one of the nine types described above behavior, also referring to authors that this is not a framework that is capable of embracing all constructs of leadership, but only explore these in detail (Bass \& Avolio, 1999). The transactional leader based more on 
its action on the legitimacy and authority expressed in behaviors associated with goals, to reward and / or punishment, while the transactional it supports more on vision, aggregation, mobilization, appeal and expression values. It is proposed by the authors expressed in various works already referenced, the leader behavior (ideal) present low frequency passive and switch behaviors associated with transactional and transformational styles as their own contingent of the group, the nature of the challenges and to the leader himself. Refer however, that the effective leader is one dominated by transformational behaviors, followed by behavior reinforcement and rewards (transactional) may even reach a stage where passive behaviors can be positive for the group, and results generators. In terms of recognition by the followers, and regardless of cultural context, gain particular relevance transformational behaviors (Avolio and Bass, 1995; Bass \& Avolio, 1989;. Offermann Kennedy \& Wirtz, 1994), being those that lead to positive change, namely: development of people based on common values and ideals; involvement and sharing in a common vision; greater competence and efficiency at work, individual and group; greater appetite for the collective interest at the expense of staff.

In recent decades, numerous evaluations of the effectiveness of leadership and contours of the same were assessed using the Multifactor Leadership Questionnaire - MLQ (Bass \& Avolio, 1995, 2004), having become a recurrent evaluation instrument styles and effectiveness of processes leadership, in various contexts, activities and even different countries (Judge \& Piccolo, 2004).

The MLQ is a standard tool for assessing leadership behavior, in three dimensions presented above: transactional, transformational and laissezfaire (Garden Rd, \& City, 1992), available in several languages and used by academics and professionals widely (Leong Fisher, 2011). For the Portuguese reality, the instrument is tried and tested, having given body to various investigations on the subject, as identified in a recent metaanalysis (Castanheira \& Costa, 2011).

\section{Methodology}

The methodological approach to this research was quantitative and data collection process was supported by a questionnaire, using the google forms platform. The first part of the questionnaire is the characterization of the respondents while the second part is the Multifactorial Leadership Questionnaire developed by Bass and Avolio (1994). The respondent's rating was based on their leadership style as defined by the Multi-factor Leadership Questionnaire.

The MLQ Manual (Bass, 1997) refers the leadership styles: a) transformational Leadership which refers to the charisma of the leader, and emphasizes a collective sense of mission and values; b) transactional leadership focuses on achieving the goals. Leader acts according to the power and formal authority conferred upon it; c) laissez-faire or passive leadership is considered by the authors as a component of non-leadership. The statistical analysis of data was mainly descriptive, using IBM SPSS. Examining the leadership styles which emerged from the analysis (Table 1), it can be concluded that: - $68 \%$ of leaders consider a 'Fairly Often' or 'frequently, if not always' use of the Transformational Leadership, while $59 \%$ of leaders consider a 'fairly Often' or 'frequently, if not always' use of the Transactional Leadership and finally, $66 \%$ of the leaders believe that 'never' or 'rarely' use the Laissez-faire Leadership.

\section{Findings}

Examining leadership styles which emerged from the analysis (Table 2), it appears that: - $68 \%$ of leaders consider using 'Fairly Often' or 'frequently, if not always' the Transformational Leadership, while 59\% of leaders consider using 'fairly Often' or 'frequently, if not always' the Transactional Leadership and finally, $66 \%$ of leaders believe that 'never' or 'rarely' use the Laissez-faire Leadership.

Table 2 - Leadership Styles - Descriptive analysis 1 - Transformational; 2 - Transactional; 3 - Laissez- Faire

\begin{tabular}{|l|r|r|r|r|r|r|}
\hline & \multicolumn{2}{|c|}{1} & \multicolumn{2}{c|}{3} \\
\cline { 2 - 7 } & $\begin{array}{c}\text { Relative } \\
\text { frequency } \\
(\%)\end{array}$ & $\begin{array}{c}\text { Cumvlative } \\
\text { Relative } \\
\text { Frequency (\%) }\end{array}$ & $\begin{array}{c}\text { Relative } \\
\text { frequency } \\
(\%)\end{array}$ & $\begin{array}{c}\text { Cumdlat ive } \\
\text { Relative } \\
\text { Frequency (\%) }\end{array}$ & $\begin{array}{c}\text { Relative } \\
\text { frequency } \\
(\%)\end{array}$ & $\begin{array}{c}\text { Cumulative } \\
\text { Relative } \\
\text { Frequency (\%) }\end{array}$ \\
\hline 0 - Not at all & $0,0 \%$ & $0,0 \%$ & $2,3 \%$ & $2,3 \%$ & $34,1 \%$ & $34,1 \%$ \\
\hline 1 - Once in a while & $2,3 \%$ & $2,3 \%$ & $9,1 \%$ & $11,4 \%$ & $31,8 \%$ & $65,9 \%$ \\
\hline 2 - Somet imes & $29,5 \%$ & $31,8 \%$ & $29,5 \%$ & $40,9 \%$ & $22,7 \%$ & $88,6 \%$ \\
\hline 3 - Fairly often & $47,7 \%$ & $79,5 \%$ & $43,2 \%$ & $84,1 \%$ & $9,1 \%$ & $97,7 \%$ \\
\hline $\begin{array}{l}\text { 4- Frequently, } \\
\text { if not alusys }\end{array}$ & $20,5 \%$ & $100,0 \%$ & $15,9 \%$ & $100,0 \%$ & $2,3 \%$ & $100,0 \%$ \\
\hline
\end{tabular}

According to Bass and Avolio, the most effective leader has a higher score in the categories of Transformational Leadership, followed by Contingent Reward, Management by Exception - Active and Passive, and finally, the Laissez Faire.

Table 3 - Leadership Styles - Analysis by Dimensions

\begin{tabular}{|c|c|c|}
\hline & Dimension & Leader \\
\hline \multirow{5}{*}{$\begin{array}{c}\text { Tnansformational } \\
\text { Leadership - }\end{array}$} & Idealized Infuence (Attribute) & \multirow{5}{*}{3,87} \\
\hline & Idealized Infuence (Behavior) & \\
\hline & Inspirational Motivation & \\
\hline & Intellectual Stimulation & \\
\hline & Individual Considenation & \\
\hline \multirow{2}{*}{$\begin{array}{l}\text { Trans actional } \\
\text { Leadership - }\end{array}$} & Contingent Reward & \multirow{2}{*}{3,2} \\
\hline & Management by Exception (Active) & \\
\hline \multirow{2}{*}{$\begin{array}{l}\text { Laissez-faire } \\
\text { Leadership }\end{array}$} & Laissez-faire & \multirow{2}{*}{2,1} \\
\hline & Management by Exception (Passive) & \\
\hline
\end{tabular}

From the leader's perspective, the transformational leadership is the most predominant (3.87) and the category with the highest score is the Inspirational Motivation (4.1) which shows a higher score than the leadership style. Leaders believe that they promote an inspirational leadership through their ability to inspire and motivate team members; the enthusiasm and optimism of leaders allow the individual to foster a team spirit.

\section{Conclusion}

This study aimed to raise awareness of the importance of the leadership style in developing the teams and their motivation. Considering our results, it is interesting to note that from the research emerges the predominance of transformational leadership style according to the Project Managers perceptions.

There are two main conclusions to be taken of this study: that the leadership profile is enhanced by the specific training in project management and also that the transformational leadership profile is far more efficient in project management. In this context it's possible to state that, on one side, the transactional leadership is not inefficient but it has some kind of limitation regarding the commitment between a leader and a follower; on the other side, the transformational leadership is the one through which the projects will achieve more success and will reach the targeted benefits and efficiency. In conclusion it is possible to state that a 
mix of the two models: Transactional and Transformational shall be a better choice for an effective leadership and for perfect results inside an organization.

\section{References}

- Andersen, ES, \& Jessen, SA (2003). Organisations maturity in Project. International Journal of Project Management, 21 (6), 457461. doi: 10.1016 / S0263-7863 (02) 00088-1, Crossref

- Antonakis, J. (2002). House (2013), The Full-Range Leadership Theory: The Way Forward. Transformational and Charismatic Leadership: The Road Ahead 10th Anniversary Edition (Monographs in Leadership and Management, Volume 5) Emerald Group Publishing Limited, 5, 3-33.

- Avolio, BJ, \& Bass, BM (1995). Individual consideration viewed ' at multiple levels of analysis: A multi-level framework for examining the diffusion of transformational leadership. The Leadership Quarterly, 6 (2), 199-218, Crossref

- Avolio, BJ, \& Bass, BM (2004). MLQ: Multifactor leadership questionnaire. Mind Garden.

- Avolio, BJ, Bass, BM, \& Zhu, FWW (2004). Multifactor leadership questionnaire: manual and sampler in September Redwood City, CA: Mind Garden.

- Avolio, BJ, \& Yammarino, FJ (1990). Operationalizing charismatic leadership using the levels-of-analysis framework. The Leadership Quarterly, 1 (3), 193-208, $\underline{\text { Crossref }}$

- Avolio, BJ, Yammarino, FJ, \& Bass, BM (1991). Identifying common methods variance with data collected from a single source: An unresolved sticky issue. Journal of Management, 17 (3), 571587, $\underline{\text { Crossref }}$

- Bass, BM (1985). Leadership and performance beyond expectations. Free Press; Collier Macmillan.New York.

- Bass, BM (1998). Transformational leadership: industrial, military, and educational impact. New Jersey: Lawrence Erlbaum Associates.

- Bass, BM, \& Avolio, BJ (1989). Potential biases in leadership measures: How prototypes, leniency, and general satisfaction relate to ratings and rankings of transformational and transactional leadership constructs.Educational and psychological measurement, 49 (3), 509-527, $\underline{\text { Crossref }}$

- Bass, BM, \& Avolio, BJ (1993). Transformational leadership and organizational culture. Public administration quarterly, 112-121.

- Bass, BM, \& Avolio, BJ (1993a). Transformational leadership: A response to critiques. In Chemers MM \& Ayman R. (Eds.), Leadership Theory and research: Perspectives and directions. New York: Academic Press

- Bass, BM, \& Avolio, BJ (1994). Improving organizational effectiveness through transformational leadership. Newbury Park, CA: Sage.

- Bass, BM, \& Avolio, BJ (1994). Transformational leadership and organizational culture. The International Journal of Public Administration, 17 (3-4), 541-554, $\underline{\text { Crossref }}$

- Bass, BM, \& Avolio, BJ (1995). MLQ Multifactor leadership questionnaire. Redwood City. CA: Mind Garden.

- Bass, BM, \& Avolio, BJ (1997). Full Range leadership development: Manual for the Multifactor Leadership Questionnaire. California: Mind Garden.

- Bass, BM, \& Avolio, BJ (1999). Training full range leadership: A resource guide for training with the MLQ. California: Mind Garden.

- Bass, BM, \& Avolio, BJ (2000). Multifactor Leadership Questionnaire: MLQ; Sampler Set; Technical Report, Form Leader,
Rater Form, and Scoring Key for MLQ Form 5X-short. Mind Garden.

- Bass, BM, \& Steidlmeier, P. (1999). Ethics, character, and authentic transformational leadership behavior. The leadership quarterly, 10 (2), 181-217, $\underline{\text { Crossref }}$

- Bass, BBM \& Stogdill, R. (1990). . Handbook of leadership Theory, Research \& Managerial ..., 3rd (3), 2415. doi: 10.1111 / j.14640597.2004.00176.x

- Blake, RR, Mouton, JS, Barnes, LB, \& Greiner, LE (1964). Breakthrough in organization development. Harvard Business Review, 42, 37-59.

- Boyatzis, R., Goleman, D., \& Rhee, K. (2000). Clustering competence in emotional intelligence: Insights from the Emotional Competence Inventory (ECI) Handbook of Emotional Intelligence. Retrieved from http://www.eiconsortium.org/pdf/eci_acticle.pdf

- Burns JM (1978). Leadership. New York: Harper and Row Publishers. Leadership Quarterly. 2 (1).

- Carter, MZ, Armenakis, A., Field, H., \& MOSSHOLDER, K. (2013). Transformational leadership, relationship quality, and employee performance incrementak during continuous organizational change. Journal of Organizational Behavior, 34, 942958. doi: 10.1002 / job. 1824

- Castanheira, P., \& Costa, JA (2011). In search of transformational leadership: A (Meta) analysis focused on the Portuguese reality Proceeding - Social and Behavioral Sciences. doi: $10.1016 /$ j.sbspro.2011.04.045

- Clarke, N. (2010). Emotional intelligence and its relationship to transformational leadership and key competences project manager. Project Management Journal, 41 (2), 5-20Geoghegan, L., \& Dulewicz, V. (2008). The project managers' leadership competencies Contribute to project success? Project Management Journal, 39 (4), 58-67.

- Conger, JA, \& Kanungo, RN (1987). Toward the Behavioral Theory of Charismatic Leadership in Organizational Settings.pdf. Academy of Management Review, Vol. 12 (No. 4), 637-647.

- Conger, JA, \& Kanungo, RN (1988). The empowerment process: Integrating theory and practice. Academy of management review, 13 (3), 471-482.

- Eskerod, P., \& Riis, E. (2009). The art of managing relationships in interorganizational collaboration. Project Management Journal. John Wiley \& Sons, Inc./Education. doi: 10.1002 / pmj

- Fiedler, FE (1986). The contribution of cognitive resources and leader behavior to organizational performance1. Journal of Applied Social Psychology, 16 (6), 532-548, Crossref

- Fiedler, FE (1987). A theory of leadership effectiveness (1st ed.). New York: McGraw-Hill.

- Fiedler, FE, \& Garcia, JE (1987). New approaches to effective leadership: Cognitive resources and organizational

- Fiedler, FE (1991). A Theory of Leadership Effectiveness. Journal of Management. Vol. 17 Issue 2, P501. 3p.

- Fiedler, FE (1996). Reflections by an accidental theorist. The Leadership Quarterly, 6 (4), 453-461, $\underline{\text { Crossref }}$

- Fiedler, FE (1996). Research on leadership selection and training: One view of the future. Administrative Science Quarterly, 241-250, Crossref

- Geoghegan, L., \& Dulewicz, V. (2008). The project managers' leadership competencies Contribute to project success? Project Management Journal. doi: 10.1002 / pmj.20084

- Garden, M., Rd, W, \& City, R. (1992). Multifactor Leadership Questionnaire (MLQ) Form 6S. 
- Goleman, D. Working with emotional intelligence. Lisbon: Issues and Debates, 2000. ISBN 972-759-180-9.

- Goleman, D. (2000). Leadership que gets results.Harvard Business Review, (2), 78-90

- Hersey, P., \& Blanchard, KH (1988). Hersey and Blanchard_Management of Organizational Behavior_Utilizing Human Resources (Book). Englewood Cliffs, NJ: Prentice-Hall.

- House, RJ, \& Mitchell, TR (1975). Path-goal theory of leadership (No. TR-75-67). WASHINGTON UNIV SEATTLE DEPT OF PSYCHOLOGY.

- House, RJ (1976). A 1976 theory of charismatic leadership. In Hunt, JG, \& Larson, LL (eds.). (1977). Leadership: The cutting edge. Southern Illinois University Press.

- House, RJ (1996). Path-goal theory of leadership: Lessons, legacy, and a reformulated theory. The Leadership Quarterly, 7 (3), 323-352, Crossref

- Judge, T., \& Piccolo, RF (2004). Transformational and transactional leadership: a meta-analytic test of Their relative validity The Journal of Applied Psychology.. doi: 10.1037 / 0021-9010.89.5.755

- Keegan, AE, \& Den Hartog, DN (2004). Transformational leadership in a project-based environment: a comparative study of the leadership styles of project managers and line managers International Journal of Project Management, 22 (8), 609-617. doi: 10.1016 / j.ijproman.2004.05.005

- Khan, MI, Khan, MA, Saeed, T. Khan, MS, \& Sanaulla. (2011a). Linking emotional intelligence and transformational leadership: services sector of pakistan Review of Innovation, Creativity \& Management, 4 (13), 43-53.

- Khan, MI, Khan, MA, Saeed, T. Khan, MS, \& Sanaulla. (2011b). Linking emotional intelligence and transformational leadership: services sector of pakistan Review of Management Innovation \& Creativity, 4 (13), 43-53.

- Leban, W., \& Zulauf, C. (2004). Linking emotional intelligence abilities and transformational leadership styles. Leadership \& Development Organization Journal, 25 (7), 554-564, $\underline{\text { Crossref }}$

- Leong, LYC, \& Fischer, R. (2011). Is universal transformational leadership? The meta-analytical investigation of multifactor leadership questionnaire means across cultures. Journal of Leadership \& Organizational Studies, 18 (2), 164-174, Crossref

- Lewin, K., Lippit, R. \& White, R.K. 1939 'Patterns of aggressive behavior in experimentally created social climates' Journal of Social Psychology, 10, pp. 271-301, Crossref

- Likert, R. (1967). The human organization: its management and values. New York. McGraw-Hill

- Lowe, KB, Kroeck, KG, \& Sivasubramaniam, N. (1996). Effectiveness correlates of transformational and transactional leadership: A meta-analytic review of the literature MLQ Leadership Quarterly, 7 (3), 385-425. doi: 10.1016 / S1048-9843 (96) 90027-2

- Lowe, KB, Kroeck, KG, \& Sivasubramaniam, N. (1996). Effectiveness correlates of transformational and transactional leadership: A meta-analytic review of the literature MLQ. The Leadership Quarterly, 7 (3), 385-425, Crossref

- Offermann, LR, Kennedy, JK, \& Wirtz, PW (1994). Implicit leadership theories: Content, structure, and generalizability. The Leadership Quarterly, 5 (1), 43-58, Crossref

- Prabhakar, GP (2005). Switch Leadership in Projects: an Empirical Study Reflecting the Importance of Transformational Leadership on Project Success across Twenty-Eight Nations. . Project Management Journal, (1997), 53-61.
- Popper, M., \& Mayseless, O. (2007). The building blocks of leader development: Conceptual psychological framework. Leadership \& Development Organization Journal, 28 (7), 664-684, Crossref

- Rashid Rehman, R., \& Waheed, A. (2012). Transformational Leadership Style of the Predictor Decision Making Styles: Moderating Role of Emotional Intelligence Pakistan Journal of Commerce \& Social Sciences.. Retrieved from http://search.ebscohost.com/login.aspx?direct=true \&db=bth\&AN= 85354490\&site $=$ ehost-live

- Rowold, J. (2005). Psychometric properties of the German translation by Jens Rowold.

- Stogdill, RM (1948). Personal factors associated with leadership: A survey of the literature. The Journal of Psychology, 25 (1), 35-71, Crossref

- Stogdill, RM (1974). Handbook of leadership: A survey of theory and research. Free Press

- Thite, M. (1997). Relationship between leadership and information technology project success. Retrieved from http://researchbank.swinburne.edu.au/vital/access/services/Downlo ad/swin:7441/SOURCE2, Crossref

- Thite, M. (1999). Identifying characteristics of key technical project leadership.Leadership \& Development Organization Journal, 20 (5), 253-261, Crossref

- Thite, M. (2000). Leadership styles in information technology projects.International Journal of Project Management, 18 (4), 235241.

- Turner, JR, \& Müller, R. (2005). The project manager's leadership style as a success factor on projects:. The literature review Project Management Journal, 36, 49-61. 13p. Diagram 1.

- Yammarino, FJ, \& Bass, BM (1990). Transformational Leadership and Multiple Levels of Analysis. Human Relations. doi: 0803973233, $\underline{\text { Crossref }}$

- Yammarino, FJ, Spangler, WD, \& Bass, BM (1993). Transformational leadership and performance: A longitudinal investigation. The Leadership Quarterly 4 (1), 81-102, Crossref

- Yukl, G. (1989). Managerial leadership: A review of theory and research.Journal of management, 15 (2), 251-289, Crossref

- Yukl, G. (1999). An Essay on Evaluative Current Conceptions of Effective Leadership. European Journal of Work and Organizational Psychology, 8 (1), 33-48. doi: 10.1080 / 135943299398429, $\underline{\text { Crossref }}$ 